\title{
GENETIC DIVERSITY IN A POPULATION OF CREOLE MAIZE (Zea mays L.) EVALUATED BY MICROSATELLITE MARKERS IN PUERTO LIBERTADOR, CORDOBA
}

\section{DIVERSIDAD GENÉTICA EN UNA POBLACIÓN DE MAÍZ CRIOLLO (Zea mays L.) EVALUADA MEDIANTE MARCADORES MICROSATÉLITES EN PUERTO LIBERTADOR, CÓRDOBA}

\author{
Enrique Pardo Pérez ${ }^{1}$, Teodora Cavadía Martínez ${ }^{2}$, Yurany Herrera Vanegas ${ }^{3}$.
}

${ }^{1}$ Bachelor degree in Biology-Chemistry, M.Sc. Biology, Ph.D. in Science. University of Córdoba, $6^{\text {th }}$ Avenue No. 76-103, Montería, Colombia, e-mail: epardop@correo.unicordoba.edu.co, (iDhttp://orcid.org/0000-0002-6467-5790; ${ }^{2}$ Bachelor degree in Biology-Chemistry, M.Sc. Biology. University of Córdoba, $6^{\text {th }}$ Avenue No. 76-103, Montería, Colombia, e-mail: tcavadia@ correo.unicordoba.edu.co, Dhttps://orcid.org/0000-0002-3553-6046; ${ }^{3}$ Biologist. University of Córdoba, $6{ }^{\text {th }}$ Avenue No. 76 103, Montería, Colombia, e-mail: yuranysherrerav@gmail.com, (iDhttps://orcid.org/0000-0002-8147-5459

\author{
Rev. U.D.C.A Act. \& Div. Cient. 21(2):359-365, Julio-Diciembre, 2018 \\ https://doi.org/10.31910/rudca.v21.n2.2018.981
}

Open access article published by Revista U.D.C.A Actualidad \& Divulgación Científica under a Creative Commons CC BY-NC 4.0 International License

\begin{abstract}
Maize a plant of Mesoamerican origin, has evolved in different microenvironments, generating the great diversity of maize that exists in the world. In order to determine the genetic diversity of a population of Creole maize, twelve microsatellite markers were evaluated in 30 accessions, in Puerto Libertador, Córdoba. The DNA of each accession was extracted using the PROMEGA kit, the markers were amplified by the PCR technique and the amplicons were run on polyacrylamide gels, the gels were digitalized and the molecular sizes were determined by an exponential model. Results showed a total of 66 alleles and an average of alleles of 5.5, the expected heterozygosity was 0.655 , the values of the polymorphic information content (PIC) ranged from 0.352 to 0.838 , with an average of 0.592 and the Hardy-Weinberg equilibrium showed imbalance $(p<0.05)$. This work revealed that the studied accessions of Creole maize showed a high degree of polymorphism, high genetic variability and microsatellite markers were the appropriate for the evaluation of genetic diversity. This information shows to be useful for the conservation and protection of the genetic diversity of the studied Creole Maize.
\end{abstract}

Keywords: alleles, genetic diversity, heterozygosity, corn, Hardy-Weinberg equilibrium.

\section{RESUMEN}

El maíz una planta de origen mesoamericano, se ha desarrollado en los más variados microambientes, lo que ha generado una gran diversidad de variedades alrededor del mundo. Con el objetivo de determinar la diversidad genética de una población de maíz criollo, se evaluaron doce marcadores microsatélite, en 30 accesiones, en Puerto Libertador, Córdoba. El ADN de cada accesión fue extraído, mediante el kit de PROMEGA; los marcadores se amplificaron, mediante la técnica de PCR y los amplicones, se corrieron en geles de poliacrilamida. Los geles fueron digitalizados y los tamaños moleculares se determinaron, mediante un modelo exponencial. Los resultados mostraron un total de 66 alelos y un promedio de alelos de 5,5; la heterocigosidad esperada fue 0,655 . Los valores del contenido de información polimórfica (PIC) variaron de 0,352 a 0,838, con un promedio de 0,592 y la prueba de Hardy-Weinberg mostró desequilibrio $(p<0,05)$. Este trabajo reveló que las accesiones de maíz criollo estudiadas mostraron alto grado de polimorfismo, alta variabilidad genética y los marcadores microsatélites resultaron los apropiados para la evaluación de la diversidad genética. Esta información muestra ser útil para la conservación de la diversidad genética del maíz criollo estudiado y su protección.

Palabras clave: alelos, diversidad genética, heterocigosidad, equilibrio Hardy-Weinberg. 


\section{INTRODUCTION}

Maize, corn (Zea mays L.) an annual monoecious plant, which belongs to the Poaceae family, has a cylindrical stem, long and thick leaves, its height ranges from one to three meters, being a species that reproduces by cross-pollination, with feminine and masculine flowers located at different places of the plant (Sánchez \& Pérez, 2014).

This species has evolved in different microenvironments, which has generated a great genetic variability; maize is native and was domesticated by the indigenous peoples in the center of Mexico, since about 10.000 years ago, being one of the main food resources for human consumption, it also has a great socio-economic and cultural importance (González Castro et al. 2013).

For centuries the activities of farmers, from the first agricultural societies to the present ones have allowed the selection and development of new varieties of maize, which are commonly known as Creole maize, which have adapted to the different ecological, agronomic, climatic and soil conditions, covering the nutritional and cultural requirements. Being subjected to important processes of genetic erosion, related to the introduction of hybrid maize and market demands (Tadeo et al. 2015). It is important to mention the fact that, in February 2007, the ICA decreed commercial plantings of three varieties of transgenic maize, namely: Roundup Ready maize (from Monsanto), Herculex I Bt maize (from Dupont) and Bt YieldGard MON 810 maize (from Monsanto), in the departments of Córdoba, Sucre, Huila and Tolima (Grupo Semillas, 2007); this unthinking and unilateral decision was made without studies that demonstrate the safety and convenience of these technologies for Colombia and its farmers, seriously affecting the native corn genetic diversity.

Lost of genetic variability lead to the loss of genetic and biological diversity, therefore, without genetic variability, a population cannot evolve in response to changes in environmental variables facing an increased risk of extinction (Gálvez et al. 2010). For this reason, molecular techniques have been used as an efficient tool for investigations of variability and genetic diversity of populations, being used in the protection, characterization and conservation of plants. One of the most recognized techniques is the use of microsatellites, this type of molecular markers based on DNA have been used to identify races and determine the genetic structure of various endemic lines of interest, microsatellites or short repeated sequences (STRs) have been widely used for the characterization of genetic variability and the description of genetic structure of maize populations, for having high reliability and automation (Bedoya et al. 2010).
At the international level, molecular markers have become important genetic indicators to determine genetic diversity and within these microsatellites are determinant because of their codominant character and their wide use in a wide range of crop species, including Maize (Elçi \& Hançer, 2015). Also Salami et al. (2016), characterized accessions of maize through microsatellites in Benin, reporting a high polymorphism and genetic differentiation among the accessions, information necessary to improve the production and conservation of Maize.

The objective of this work was to determine the genetic diversity of a population of Creole maize (Zea mays L.) by using STR-type molecular markers in Puerto Libertador Córdoba-Colombia in order to broaden knowledge about the genetic diversity of Creole maize and contribute to the approach of conservation strategies.

\section{MATERIALS Y METHODS}

Study area. The origin of the studied plant material was collected in farms of Puerto Libertador (7 $7^{\circ} 53^{\prime} 17^{\prime \prime} N$ N 75 40'18" W), in the department of Córdoba, Colombia.

Collection of samples. Samples of 30 maize accessions were taken in Puerto Libertador, deposited in resalable bags, where silica gel was added for dehydration; they were labeled and transported to the Genetics Laboratory of the University of Córdoba, for the corresponding analysis.

Extraction of genomic DNA. Fragments of dry foliar tissue were placed in a porcelain capsule with liquid nitrogen, each of the samples was macerated until a very fine powder was obtained and they were stored at $-20^{\circ} \mathrm{C}$ until their later use. The extraction of the genomic DNA was carried out from $75 \mathrm{mg}$ of the macerated material, using the extraction and purification kit of Wizard ${ }^{\circledR}$ Genomic DNA Purification (PROMEGA).

Quantification of DNA. In order to evaluate the quality and to estimate the amount of DNA obtained in the extraction, a $1 \%$ agarose gel was made in a horizontal electrophoresis chamber (Multi Sub Choice Trio) and run at $100 \mathrm{w}$ for $40 \mathrm{~min}$. $5 \mu$ l of DNA from each sample and $5 \mu \mathrm{l}$ of molecular weight marker with range 100-10000bp, GeneRuler 100pb Plus DNA Ladder (Thermo Scientific) were seeded. The concentration of the extracted DNA was estimated by comparing the bands of the molecular weight marker.

Polymerase chain reaction (PCR) and fragment analysis. The microsatellite markers (Table 1 ) were amplified by the PCR technique. The reaction mixture had a final volume of $25 \mu \mathrm{L}$, which included $0.2 \mu \mathrm{M}$ of dNTPs, $1.5 \mathrm{X}$ of Buffer, $1.5 \mu \mathrm{M}$ of $\mathrm{MgCl}_{2}, 0.5 \mu \mathrm{M}$ of each primer (Forward and reverse), 
$0.05 \mathrm{U} / \mu \mathrm{l}$ of enzyme Taq polymerase, $3.33 \mathrm{ng} / \mu \mathrm{L}$ of genomic DNA and sterile water to reach the final volume.

The PCR reaction was performed in a Bio-Rad T100 ${ }^{\mathrm{TM}}$ thermocycler using the PCR Tochdown technique, which consisted of an initial denaturation phase of $95^{\circ} \mathrm{C}$ for $3 \mathrm{~min}$, 12 cycles of: 30 s denaturation at $95^{\circ} \mathrm{C}, 30 \mathrm{~s}$ of annealing temperature from $62^{\circ} \mathrm{C}$ to $57^{\circ} \mathrm{C}$ reducing $1^{\circ} \mathrm{C}$ every 2 cycles and an extension to $72^{\circ} \mathrm{C}$ for $1 \mathrm{~min} ; 23$ cycles with $30 \mathrm{~s}$ of denaturation at $95^{\circ}, 56^{\circ} \mathrm{C}$ of annealing for 30 s and extension at $72^{\circ} \mathrm{C}$ for $1 \mathrm{~min}$; and a final extension of $5 \mathrm{~min}$ at $72^{\circ} \mathrm{C}$.

The PCR products were separated by vertical electrophoresis in denatured (6 mol L-1 urea) $10 \%$ polyacrylamide gel (acrylamide: bisacrylamide, 29: 1) in a Mini-Protean II Biorad ${ }^{\circledR}$ camera (Applied Biosystems, Foster City, USA.)
(Tsang et al. 1986). The bands were visualized by staining with silver nitrate (Qiu et al. 2012), using DNA ladder, where the range of the molecular weight marker used ranged between 50 and $500 \mathrm{bp}$. The gels were photographed with a CANON ELPH180 IS camera and the determination of the allelic size was carried out by the Image J program (Abràmoff et al. 2004) where, by pixelation of the amplified bands, the allelic sizes were determined using the software Past 3.14 (Hammer et al. 2001).

Statistical analysis. With the information obtained from the gels and using the software GENALEX 6 (Peakall and Smouse, 2006) it was calculated: number of alleles, effective number of alleles (Na), allelic frequencies, observed and expected heterozygosity values ( $\mathrm{Ho}$ and $\mathrm{He}$ ), fixation index (F) and Hardy-Weinberg equilibrium (HW). The PIC (Content

Table 1. Characteristics of the microsatellite primers of Zea mays L. (12), sequence of primers, allele number and allelic range (bp).

\begin{tabular}{|c|c|c|c|}
\hline Locus & Sequence & Number of alleles & Allelic range (bp) \\
\hline Umc1225 & $\begin{array}{l}\text { F: CTAGCTCCGTGTGAGTGAGTGAGT } \\
\text { R: TTCCTTCTTTCTTTCCTGTGCAAC }\end{array}$ & 8 & $85-123$ \\
\hline Umc1335 & $\begin{array}{l}\text { F: ATGGCATGCATGTGTTTGTTTTAC } \\
\text { R: ACAGACGTCGCTAATTCCTGAAAG }\end{array}$ & 6 & $119-144$ \\
\hline Umc1424 & $\begin{array}{l}\text { F: CCGGCTGCAGGGGTAGTAGTAG } \\
\text { R: ATGGTCAGGGGCTACGAGGAG }\end{array}$ & 6 & $112-133$ \\
\hline Umc1165 & $\begin{array}{l}\text { F: TATCTTCAGACCCAAACATCGTCC } \\
\text { R: GTCGATTGATTTCCCGATGTTAAA }\end{array}$ & 6 & $155-181$ \\
\hline Umc1403 & $\begin{array}{l}\text { F: GTACAACGGAGGCATTCTCAAGTT } \\
\text { R:TGTACATGGTGGTCTTGTTGAGGT }\end{array}$ & 7 & $122-162$ \\
\hline Phi127 & $\begin{array}{l}\text { F: ATATGCATTGCCTGGAACTGGAAGGA } \\
\text { R: AATTCAAACACGCCTCCCGAGTGT }\end{array}$ & 4 & $112-130$ \\
\hline Phi059 & $\begin{array}{l}\text { F: AAGCTAATTAAGGCCGGTCATCCC } \\
\text { R: TCCGTGTACTCGGCGGACTC }\end{array}$ & 2 & $147-157$ \\
\hline Bnlg1520 & $\begin{array}{l}\text { F: TCCTCTTGCTCTCCATGTCC } \\
\text { R:ACAGCTGCGTAGCTTCTTCC }\end{array}$ & 6 & $174-193$ \\
\hline Bnlg1740 & $\begin{array}{l}\text { F: TTTTCTCCTTGAGTTCGTTCG } \\
\text { R: ACAGGCAGAGCTCTCACACA }\end{array}$ & 11 & $112-182$ \\
\hline Phi115 & $\begin{array}{l}\text { F: GCTCCGTGTTTCGCCTGAA } \\
\text { R: ACCATCACCTGAATCCATCACA }\end{array}$ & 3 & 295-309 \\
\hline Phi031 & $\begin{array}{l}\text { F: GCAACAGGTTACATGAGCTGACGA } \\
\text { R:CCAGCGTGCTGTTCCAGTAGTT }\end{array}$ & 4 & 190-199 \\
\hline Phi056 & $\begin{array}{l}\text { F: ACTTGCTTGCCTGCCGTTAC } \\
\text { R:CGCACACCACTTCCCAGAA }\end{array}$ & 3 & $81-88$ \\
\hline Promedio & & 5,5 & - \\
\hline
\end{tabular}


of Polymorphic Information) of each microsatellite was determined by the CERVUS v. 3.0 Program (Kalinowski et al. 2007).

\section{RESULTS AND DISCUSSION}

In this study we found that the 12 analyzed molecular markers were polymorphic, presenting a total of 66 alleles, with a variation in the number of alleles between 2 (Phi59) and 11 (Bnlg1740) and the average number of alleles was 5.5 (Table 1).

For the 30 accessions of studied Creole maize, all the used microsatellite markers exhibited a high degree of polymorphism. The average allele number was 5.5, these values differ from those obtained by Fernandes et al. (2015), who reported average values of 5.7 and 2.8 alleles per locus respectively and similar to the result obtained by González Castro et al. (2013), who report values of 5.5 .

The average of the effective number of alleles was 3,356, the marker with the highest effective number of alleles was Bnlg1740 with 6,844 and Phi059 had the lowest effective number of alleles with 1,839 (Table 2).
The number of effective alleles (Na) for the population of Creole maize studied ranged between 1.81 and 6.84 with an average of 3.3 , this result $(\mathrm{Na}=3.3)$ was higher than that reported by Nyaligwa et al. (2015) $(\mathrm{Na}=2.4)$ and lower than that obtained by Mora et al. (2013) (Na = 4.8) and Vivodík et al. (2017) $(\mathrm{Na}=6.6)$.

The observed heterozygosity (Ho) average obtained for the 12 markers was 0.293, the marker Bnlg1520 obtained the highest value with 0.679 and the marker Phi31 obtained the lowest value with 0.103 . The expected heterozygosity $(\mathrm{He})$ average obtained was 0.655, the marker Bnlg1740 obtained the highest value with 0.868 , and the marker Umc1424 obtained the lowest value with 0.458 (Table 2).

The expected heterozygosity (He) average of the 12 molecular markers evaluated was 0.65 , revealing high genetic variability, as this is considered when values exceed 0.5 (Nei, 1978). This value is similar to that reported by Chen et al. (2016) $(\mathrm{He}=0.690)$ and higher than other studies such as Salami et al. (2016) ( $\mathrm{He}=0.46)$.

The percentage of heterozygous individuals behaved below $50 \%$ for the heterozygosity observed average (Ho $=0.293$ ),

Table 2. Genetic parameters calculated in Zea mays L.

\begin{tabular}{|c|c|c|c|c|c|c|}
\hline Locus & Na & Ho & He & PIC & H-W & F \\
\hline Umc1225 & 4,820 & 0.417 & 0.809 & 0.765 & $0,000^{* * * *}$ & 0.315 \\
\hline Umc1335 & 3,600 & 0.233 & 0.734 & 0.683 & $0,000^{\prime * * * *}$ & 0.513 \\
\hline Umc1424 & 1,818 & 0.133 & 0.458 & 0.412 & $0,000^{\prime * * * *}$ & 0.556 \\
\hline Umc1165 & 3,357 & 0.241 & 0.714 & 0.658 & $0,000^{\prime * * * *}$ & 0.495 \\
\hline Umc1403 & 3,982 & 0.267 & 0.762 & 0.709 & $0,000^{\prime * * *}$ & 0.474 \\
\hline Phi127 & 1,861 & 0.300 & 0.471 & 0.416 & 0,052 'ns & 0.217 \\
\hline Phi059 & 1,839 & 0.259 & 0.465 & 0.352 & $0,025^{\prime *}$ & 0.275 \\
\hline Bnlg1520 & 4,795 & 0.679 & 0.806 & 0.760 & 0,720 'ns & 0.075 \\
\hline Bnlg1740 & 6,844 & 0.233 & 0.868 & 0.838 & $0,000^{\prime * * * *}$ & 0.573 \\
\hline Phi115 & 2,379 & 0.241 & 0.590 & 0.513 & $0,000^{\prime * * * *}$ & 0.396 \\
\hline Phi031 & 2,905 & 0.103 & 0.667 & 0.598 & $0,000^{\prime * * * *}$ & 0.729 \\
\hline Phi056 & 2,069 & 0.414 & 0.526 & 0.400 & 0,502 'ns & 0.112 \\
\hline Promedio & 3,356 & 0,293 & 0,655 & 0.592 & -- & 0,536 \\
\hline
\end{tabular}

Na: Effective allele number; Ho: Heterozygosity observed, He: Heterozygosity expected; PIC: Polymorphic Information Content, HW: Hardy Weinberg equilibrium* $\mathrm{P}<0.05$, ** $\mathrm{P}<0.01$, $* * * \mathrm{P}<0.001 ; \mathrm{F}$ : fixation index. 
possibly by consanguineous mating or selection of seeds (Eguiarte et al. 2007). This value is lower than that reported by Bracco et al. (2013) (Ho = 0.341) and Chen et al. (2016) $(\mathrm{Ho}=0.380)$.

The PIC obtained for the population varied between 0.352 (Phi059) and 0.838 (Bnlg1740), these values corresponding to the markers that presented the smallest and highest number of alleles. The average number of the PIC was 0.592 (Table 2). In this study, eight markers can be considered very informative (PIC > 0.5) and four moderately informative (PIC> 0.25).

Of the 12 markers used, 8 markers can be considered very informative (PIC > 0.5) to analyze the genetic variability of the Creole maize population and 4 moderately informative (PIC $>0.25)$, with the Bnlg1740 locus of greatest value $(\mathrm{P}=$ $0.838)$ and Phi059 ( $P=0.352)$ the lowest value; these results demonstrate that microsatellite markers are appropriate for the evaluation of the genetic diversity of the species (Van et al. 2010). The average PIC (Polymorphic Information Content) obtained in the present study was 0.592, similar to that reported by Sharma et al. (2010), (PIC $=0.60)$ and Chen et al. (2016), (PIC = 0.52) and higher than that reported by Adeyemo et al. (2011) (PIC = 0.56), Fernandes et al. (2015) (PIC $=0.42)$, and lower than that reported by IgnjatovicMicic et al. (2015) (PIC = 0.822) and Vivodík et al. (2017) $(\mathrm{PIC}=0.814)$, this demonstrates the potential of microsatellites to detect differences between maize varieties (Al-Badeiry et al. 2014).

The population showed an absence of Hardy-Weinberg equilibrium ( $\mathrm{p}<0.05$ ) (Table 2). The markers Phi127 with 0.052, Bnlg1520 with 0.720, and Phi56 with 0.502 were found in Hardy-Weinberg equilibrium.

Of the 12 total markers, 9 showed imbalance, indicating that the population is not in Hardy-Weinberg equilibrium. This imbalance could be due to an excess of homozygotes, which can be attributed to inbreeding, bottlenecks, selection and domestication of plant material due to improper management of seeds by farmers (Bracco et al. 2013).

The average value of the fixation index $(\mathrm{F})$ obtained for the 12 molecular markers evaluated was 0.536 ; the marker Bnlg1520 obtained the lowest value with 0.075 and the marker Phi31 obtained the highest value of $F$ with 0.779 , revealing an increase in the number of homozygotes with respect to the total population (Table 2).

The average fixation index obtained for the 12 molecular markers evaluated was 0.536 , which may be due to external factors that intervene in the reproduction process of the plant, favoring cross-pollination or allogamy; this value is similar to that reported by Chen et al. (2016) $(F=0.45)$.

The results suggest that in order to maintain genetic diversity, it is necessary to design intervention mechanisms that not only stimulate the conservation of genetic material, but also contribute to improving the productive and economic results for farmers (Aguirre et al. 2010). allow access to the diversity of native varieties of the region, training in selection techniques and seed management to maintain valuable characteristics (Bellon et al. 2004).

Consideration should be given to prohibiting the planting of transgenic maize in the region and thus avoiding the loss of this important indigenous resource, which has been adapting to the environment for so many years, as well as the need for studies to determine the influence of the transgenic in the health of animals and humans

The microsatellites that provide the highest detection of polymorphism and therefore the highest informative quality are Umc1225, Umc1335, Umc 1165, Umc1403, Bnlg1520, Bnlg1740, Phi115 and Phi031 as they have the highest allelic richness and the highest polymorphic information content. Therefore, of the 12 markers evaluated, these six STR's molecular markers are the indicators recommended to be included in later evaluations of genetic diversity for creole maize in Colombia.

The levels of expected heterozygosity in the present study indicate that the creole maize showed high genetic variability. The value of the fixation index $(F)$ obtained revealed an increase in the number of homozygotes with respect to the total population.

It is necessary that genetic variability is further analyzed to increase knowledge about the genetic resources of the species and used for the design of strategies with characterization, production and conservation purposes.

Conflict of interests: This article was prepared and reviewed with the participation of all the authors, who declared that there is no conflict of interest, which jeopardizes the validity of the results presented. Funding: This study was funded by the University of Córdoba (Project No. FCB-01-16)

E. Pardo and T. Cavadía conceived and designed the study. Y. Herrera carried out the experiments and carried out part of the analyzes. E. Pardo and T. Cavadía analysis and interpretation of the results. E. Pardo, Y. Herrera and T. Cavadía document writing. All the authors contributed to the discussion, revision and approval of the final manuscript. 


\section{REFERENCES}

1. ABRÀMOFF, D.; MAGALHAES, P.; RAM, S. 2004. Image processing with Image J. Biophotonics Intern. (EEUU). 11(7):36-42.

2. ADEYEMO, O.; MENKIR, A.; MELAKU, G.; OMIDIJ, O. 2011. Genetic diversity assessment and relationship among tropical yellow endosperm maize inbred lines using SSR markers. Maydica (Italia). 56:1703-1709.

3. AGUIRRE, V.J.; RINCÓN, F.; RAMÍREZ, R.; COLÓN, O.G.; RAZO, M.G. 2010. Modelo para la conservación de maíces criollos en el sureste de Coahuila; México. Coahuila; México. Editorial SINAREFI; Universidad Autónoma Agraria Antonio Narro. México. 49p.

4. AL-BADEIRY, N.; AL-SAADI, A.; MERZA, T. 2014. Analysis of genetic diversity in maize (Zea mays L.) varieties using simple sequence repeat (SSR) markers. JUBPAS (Iraq). 6:1768-1774.

5. BEDOYA, S.C.; MIR, C.; CHARCOSSET, A.; WARBURTON, M. 2010. Migración del maíz a partir de su centro de origen; evidencias históricas; genéticas y paleobotánicas. Segunda Edición. Bogotá; Colombia Editorial Mundi Prensa. 227p.

6. BELLON, R.; AGUIRRE, J.; SMALE, M.; BERTHAUD, J.; ROSAS, M.; MENDOZA, J.; SOLANO, A.; MARTÍNEZ, R. 2004. Intervenciones participativas para la conservación de maíz en fincas en los Valles Centrales de Oaxaca; México. En: Chávez-Servia, J.L.; Tuxill, J.; Jarvis, D.I. (eds). Manejo de la diversidad de los cultivos en los agroecosistemas tradicionales. Instituto Internacional de recursos fitogenéticos. Cali; Colombia. p.118-123.

7. BRACCO, M.; LIA, V.; POGGIO, L.; CÁMARA, J.; GOTTLIEB, A. 2013. Caracterización genética de razas de maíz autóctonas de Misiones; Argentina. Rev. Cienc. Tecnol. (Argentina). 20:52-60.

8. CHEN, F.B.; YAO, Q.L.; LIU, H.F.; FANG, P. 2016. Evaluation on the germplasm of maize (Zea mays L.) landraces from southwest China. Genet. Mol. Res. (Brasil). 15(4):gmr15049160.

9. EGUIARTE, L.; SOUZA, V.; AGUIRRE, X. 2007. Ecología Molecular. México D.F. México. Impresora y Encuadernadora Progreso. 609p.

10. ELÇI, E.; HANÇER, T. 2015. Genetic analysis of maize (Zea mays L.) hybrids using microsatellite markers.
J. Agric. Sci. (Canadá). 21:192-198. http://dx.doi. org/10.15832/tbd.81254

11. FERNANDES, E.; SCHUSTER, I.; SCAPIM, C.; VIEIRA, E.; COAN, M. 2015. Genetic diversity in elite inbred lines of maize and its association with heterosis. Genet. Mol. Res. (Brasil). 14(2):6509-6517. https://doi. org/10.4238/2015.June.12.3

12. GÁLVEZ, D.; SALVADOR, M.; BECERRA, E.; GONZÁLEZ, M.; HERNÁNDEZ, S.; MAYEK, N. 2010. Diversidad molecular y relaciones genéticas de germoplasma de mango de Chiapas; México. Agrociencia (México). 44(8):907-915.

13. GONZÁLEZ CASTRO, M.E.; PALACIOS ROJAS, N.; ESPINOZA BANDA, A.; BEDOYA SALAZAR, C.A. 2013. Diversidad genética en maíces nativos mexicanos tropicales. Rev. Fitotecnia Mexicana. 36(3):329-328.

14. GRUPO SEMILLAS. 2007. Aprobado el maíz transgénico en Colombia. Una amenaza a la biodiversidad y la soberanía alimentaria. Revista Semillas 32:21-31.

15. HAMMER, O.; HARPER, D.; RYAN, P. 2001. Past: Paleontological statistics software package for education and data analysis. Palaeontol. Electronica (EEUU). $4(1): 1-9$.

16. IGNJATOVIC-MICIC, D.; RISTIC, D.; BABIC, V.; ANDJELKOVIC, V.; VANCETOVIC, J. 2015. A simple SSR analysis for genetic diversity estimation of maize landraces. Genetika (Serbia). 47(1):53-62.

17. KALINOWSKI, S.; WAGNER, A.; TAPER, M. 2007. Revising how the computer program CERVUS accommodates genotyping error increases success in paternity assignment. Mol. Ecol. (Inglaterra). 16(5):1099-1106. https://doi.org/10.1111/j.1365-294X.2007.03089.x

18. MORA, F.; SAAVEDRA, J.; SILVA, T.; SCAPIM, C. 2013. Bayesian analysis of the genetic structure of a Brazilian popcorn germplasm using data from simple sequence repeats (SSR). Chil. J. Agric. Res. (Chile). 73(2):99-107. http://dx.doi.org/10.4067/S071858392013000200003

19. NEI, M. 1978. Estimation of average heterozygosity and genetic distance from a small number of individuals. Genetics (EEUU). 89:583-90.

20. NYALIGWA, L.; HUSSEIN, S.; AMELEWOR, B.; GHEBREHIWO, H. 2015. Genetic diversity analysis of 
elite maize inbred lines of diverse sources using SSR markers. Maydica (Italia). 60:1-8.

21. PEAKALL, R.; SMOUSE, P. 2006. Genalex 6: Genetic analysis in Excel. Population genetic software for teaching and research. Mol. Ecol. Notes. (Inglaterra). 6(1):288-295. https://doi.org/10.1111/j.14718286.2005.01155.x

22. QIU, S.; CHEN, J.; LIN, S.; LIN, X. 2012. A comparison of silver staining protocols for detecting DNA in polyester backed polyacrylamide gel. Braz. J. Microbiol. (Brasil). 43(2):649-652. http://dx.doi.org/10.1590/ S1517-83822012000200029

23. SALAMI, H.A.; SIKA, K.C.; PADONOU, W.; ALY, D.; YALLOU, C.; ADJANOHOUN, A.; KOTCHONI, S.; BABA-MOUSSA, L. 2016. Genetic diversity of maize accessions (Zea mays L.) cultivated from Benin using microsatellites markers. Amer. J. Mol. Biol. (EEUU). 6:12-24. http://dx.doi.org/10.4236/ ajmb.2016.61002

24. SÁNCHEZ, I.; PÉREZ, E. 2014. Maíz I (Zea mays). Reduca (Biología). Serie Botánica (España). 7(2):151171.

25. SHARMA, B.; PRASANNA, M.; RAMESH, B. 2010. Analysis of phenotypic and microsatellite-based diversity of maize landraces in India; especially from the North East Himalaya region. Genetica (Holanda). 138:619331. https://doi.org/10.1007/s10709-010-9436-1
26. TADEO, M.; ZAMUDIO, B.; ESPINOSA, A.; TURRENT, A.; CÁRDENAS, A.; LÓPEZ, C.; ARTEAGA, I.; VALDIVIA, R. 2015. Rendimiento de maíces nativos e híbridos en diferente fecha de siembra y sus unidades calor. Rev. Mex. Cienc. Agríc. (Mexico). 6(1):33-43.

27. TSANG, V.; HANCOCK, K.; WILSON, M.; PALMER, D.F.; WHALEY, S.; MCDOUGAL, J.S.; KENNEDY, S. 1986. Enzyme-linked immune electro transfer blot technique (Western blot) for human T-lymphotropic virus type III/lymphadenopathy-associated virus (HTLV-III/ LAV) antibodies. Centers for Disease Control. Procedural Guide. Atlanta; USA. Immunology Series No. 15.

28. VAN, D.; MELCHINGER, A.; LEBRETON, C.; STICH, B. 2010. Population structure and genetic diversity in a commercial maize breeding program assessed with SSR and SNP markers. Theor. Appl. Genet. (Alemania). 120(7):1289-1299. https://dx.doi.org/10.10 07\%2Fs00122-009-1256-2

29. VIVODÍK, M.; PETROVIČOVÁ, L.; BALÁŽOVÁ, Ž.; GÁLOVÁ, Z. 2017. Genetic diversity of maize accessions (Zea Mays L.) cultivated from Europe using microsatellites markers. Agrobiodiversity (Ucrania) 1:524-528. http://dx.doi.org/10.15414/ /agrobiodiversity.2017.2585-8246.524-528

Received: April 19, 2018

Accepted: October 1, 2018

How to cite:

Pardo Pérez, E.; Cavadía Martínez, T.; Herrera Vanegas, Y. 2018. genetic diversity in a population of creole maize (Zea mays L.) evaluated by microsatellite markers in Puerto Libertador, Córdoba. Rev. U.D.C.A Act. \& Div. Cient. 21(2):359-365. https:// doi.org/10.31910/rudca.v21.n2.2018.981 